\title{
GOVERNMENT EXPENDITURE AND ECONOMIC GROWTH NEXUS IN MENA COUNTRIES: FREQUENCY DOMAIN SPECTRAL CAUSALITY ANALYSIS
}

\author{
Hicham AYAD \\ University Center of Maghnia, Tlemcen, Algeria \\ Corresponding author's e-mail: a_hichem210@hotmail.fr
}

\begin{abstract}
The paper aims at examining the causal relationship between economic growth and government expenditure in selected MENA countries over the period of 1987-2017. Unlike previous studies, we examine the causality in both panel data and time series data to get a clear idea about the causal relationships individually and as a full sample. We also revisited the causal relationship between the two variables within the framework of frequency domain causality. Our findings support the neutrality hypotheses in the short-run term for most of the countries. Thus, economic growth and government expenditure at most frequency levels evolve independently. On the other hand, we found the support of Wagner's law, Keynes view, neutrality and bidirectional hypotheses in the long term.
\end{abstract}

Keywords: Economic growth; Government expenditure; Frequency domain spectral causality; Wagner's law; MENA countries.

JEL Classification: $\mathrm{C} 10 ; \mathrm{H} 50 ; \mathrm{O} 10$

\section{INTRODUCTION}

After the Russian revolution in 1917 and the Great Depression in 1929, the relationship between government expenditure and economic growth became a hot debate among economists and policy-makers especially in developing countries (Karhan, 2018). An inspired result from this period is that the government expenditure can be a key determinant for the economic growth, because any changes in government spending size can directly affect the economic growth both in the short run and long run. The German economist Adolph Wagner (1893) was the first who attempted to test the causal relationship between economic growth and government expenditure (published the Foundations of Political Economy, the main idea of this book is that economic growth in any nation enhances the role of government and this is referred to as Wagner's law in the economic literature). It is clear that there is a unidirectional causal relationship running from economic growth to government expenditure not the opposite (Wagner, 1892). However, at the other extreme, according to Keynes's (1936) view (who published the General Theory of Employment, Interest and Money, in which he showed the crucial role of government in stimulating economic growth), the causal relationship is running from government expenditure to economic growth, which means that government expenditure is seen as an exogenous factor (unlike Wagner where government 
expenditure is an endogenous factor) to impulse economic growth (Ansari, Gordon and Akuamoah, 1997). In other words, according to Keynes's theory it does not matter how the money is spent but with time it will provide income and employment. However, Riedl (2010) suggests that government expenditure stimulates the long-term growth by directing and promoting productivity and employment according to education spending (human capital development), public infrastructure spending and development of institutions (Riedl, 2010).

The economic theory does not give a final decision about the causal relationship between government expenditure and economic growth. We distinguish between two major views in this area. Atkinson and Stiglitz (1980); Slemrod, Gale and Easterly (1995); Tanzi and Zee (1997) and King (2012) suggested that one of the most important economic lessons obtained from World War II was that government expenditure was the most important tool to boost economic growth due to the fiscal policies pursued by the governments around the world during and after the war. Keynes's view is supported by Babatunde (2011), Shahbaz, Khan \& Tahir (2013), Chipaumire, Ngirande and Ruswa (2014) and Ebaid and Bahari (2019). On the other hand, the Wagner's view is more supported by researchers such as Musgrave (1969), Al-Faris (2002), Menyah and Wolde-Rafael (2012), Magazzino (2012), Ono (2014), Bayrakdar et al. (2015) and many others. During the last decades, many scholars tried to examine the Wagner's view using different methods and proxies for both government expenditure and economic growth. These methods were summarised by Pula and Elshani (2018) as follows.

Equation 1: RGE = f(RGDP); Peacock-Wiseman (1961)

Equation 2: $\mathrm{RGCE}=\mathrm{f}(\mathrm{RGDP})$; Pryor (1968)

Equation 3: RGE = f(RGDP/N); Goffman (1968)

Equation 4: RGE/N = f(RGDP/N); Gupta (1967), Michas (1975)

Equation 5: RGE/ RGDP $=\mathrm{f}(\mathrm{RGDP} / \mathrm{N})$; Musgrave (1969)

Equation 6: RGE/RGDP = f(RGDP); Mann (1980)

RGE is the real government expenditure; RGDP is the real GDP; $\mathrm{N}$ is population; RGCE is the real government consumption expenditure; RGDP/N is the real GDP per capita; RGE/N is the real government expenditure per capita and $\mathrm{RGE} / \mathrm{RGDP}$ is the ratio of government expenditure to real GDP.

Akitoby, Clements, Gupta and Inchauste (2006) declared that Wagner's law is held for developed countries, while Keynes's view is held in developing countries. Ram (1986), Dar and Amir Khalkhali (2002) assumed that the relationship between economic growth and government expenditure is a U-curve relationship. Sheehey (1993) showed that while the ratio of government consumption expenditure to GDP was less than $15 \%$, economic growth and government expenditure had a positive relationship. However, if the ratio was larger than $15 \%$, the relationship became negative. Hansson and Henrekson (1994) suggested that educational expenditure had a positive effect on economic growth, consumption expenditure had a negative effect while government investment had no effect on GDP. Subsequently, the relationship and causality between economic growth and government expenditure is unclear in the literature. Agell, Lindh and Ohlsson (1997) showed that the reason 
for this fuzzy relationship was the measurement of government expenditure, the selection of samples and even the specification of econometric models.

Owing to the foregoing, we examine the causal relationship between government expenditure and economic growth in the selected MENA countries as a group and individually for the first time in the Middle East and North Africa region in order to test which view is supported in the case of each country and all the MENA countries in one sample. The present study is novel in three ways. First, we use two kinds of econometric study: the panel data analysis and time series analysis to get a clear idea about the nexus government size and economic growth. Second, our paper differs from the other studies by the use of frequency domain spectral causality depending on Breitung and Candelon (2006) procedure unlike the use of time domain causality depending on Toda and Yamamoto (1995) and Dolado and Lutkepohl (1996) procedure (TYDL). Finally, this study decomposes the total spectral interdependence into short-run and long-run periods. We structure the rest of this paper as follows. Section 2 presents the modern literature review; Section 3 focuses on the methodology, data and model of study. Section 4 presents the empirical results inspired from the econometric study, and finally Section 5 concludes the study.

\section{LITERATURE REVIEW}

There are five possible hypotheses to explain the nexus between economic growth and government expenditure. The first is the Wagner's law hypothesis or economic growth leading to government expenditure, which is the most prevalent in the literature; the Wagner's law hypothesis suggests that an increase in real GDP and productivity in the economy resultantly causes an increase in the government size (the ratio of government expenditure to the total output of the economy). The second is the Keynes's view hypothesis or government spending leading to economic growth; this hypothesis argues that the government spending can stimulate the economic growth both in short-run and long-run terms and any increase in the government size will cause an increase in the total output of economy. The third hypothesis is the bidirectional causal relationship, which suggests that government spending and economic growth lead/ follow each other. The fourth hypothesis is the neutrality (no causal relationship), which suggests that government spending and economic growth neither lead nor follow each other, and the last hypothesis is the U-curve hypothesis. According to Ram (1986) and Armey (1995), there is a non-linear relationship between the two variables, which suggests a positive relationship up to a certain threshold and the negative relationship beyond this threshold. All these hypotheses have been validated in many empirical studies, especially with the causality testing. Table 1 presents a summary of modern studies.

Table 1. Summary of Empirical Studies

\begin{tabular}{|l|l|l|l|l|}
\hline Author & Period & Sample & $\begin{array}{l}\text { Econometric } \\
\text { approach }\end{array}$ & Results \\
\hline Islam (2001) & $1929-1996$ & The USA & $\begin{array}{l}\text { Co-integration and } \\
\text { causality analysis }\end{array}$ & Wagner's law \\
\hline
\end{tabular}




\begin{tabular}{|c|c|c|c|c|}
\hline Burney (2002) & 1969-1995 & Kuwait & $\begin{array}{l}\text { Co-integration and } \\
\text { causality analysis }\end{array}$ & Wagner's law \\
\hline Al-Faris (2002) & 1970-1997 & Gulf countries & $\begin{array}{l}\text { Co-integration and } \\
\text { causality analysis }\end{array}$ & Wagner's law \\
\hline Halicioĝlu (2003) & 1960-2000 & Turkey & $\begin{array}{l}\text { Co-integration and } \\
\text { causality analysis }\end{array}$ & Wagner's law \\
\hline $\begin{array}{l}\text { Abu Bader and Abu } \\
\text { Qarn (2003) }\end{array}$ & 1967-1998 & $\begin{array}{l}3 \text { MENA } \\
\text { countries }\end{array}$ & $\begin{array}{l}\text { Co-integration and } \\
\text { causality analysis }\end{array}$ & Bidirectional \\
\hline $\begin{array}{l}\text { Dritsakis and } \\
\text { Adamopoulos (2004) }\end{array}$ & 1960-2000 & Greece & $\begin{array}{l}\text { Granger causality } \\
\text { analysis }\end{array}$ & $\begin{array}{l}\text { Keynes's } \\
\text { view }\end{array}$ \\
\hline $\begin{array}{l}\text { Loizides and } \\
\text { Vamvoukas (2005) }\end{array}$ & 1960-1995 & $\begin{array}{l}\text { Ireland, Greece } \\
\text { and the UK }\end{array}$ & $\begin{array}{l}\text { Trivariate Granger } \\
\text { causality }\end{array}$ & $\begin{array}{l}\text { Keynes's } \\
\text { view }\end{array}$ \\
\hline Jiranyakul (2013) & 1993-2006 & Thailand & $\begin{array}{l}\text { Granger causality } \\
\text { analysis }\end{array}$ & $\begin{array}{l}\text { Keynes's } \\
\text { view }\end{array}$ \\
\hline $\begin{array}{l}\text { Narayan, Prasad and } \\
\text { Singh (2008) }\end{array}$ & 1970-2002 & Fiji & $\begin{array}{l}\text { Co-integration } \\
\text { analysis }\end{array}$ & Wagner's law \\
\hline $\begin{array}{l}\text { Liu, Hsu and Younis } \\
\text { (2008) }\end{array}$ & 1974-2002 & The USA & $\begin{array}{l}\text { Granger causality } \\
\text { analysis }\end{array}$ & $\begin{array}{l}\text { Keynes's } \\
\text { view }\end{array}$ \\
\hline $\begin{array}{l}\text { Kalam and Aziz } \\
\text { (2009) }\end{array}$ & 1976-2007 & & Bangladesh & Wagner's law \\
\hline $\begin{array}{l}\text { Abdullah and } \\
\text { Maamor (2010) }\end{array}$ & 1970-2007 & Malaysia & $\begin{array}{l}\text { ARDL bound testing } \\
\text { analysis }\end{array}$ & Wagner's law \\
\hline Babatunde (2011) & 1970-2006 & Nigeria & $\begin{array}{l}\text { ARDL bound testing, } \\
\text { Toda Yamamoto } \\
\text { causality analysis }\end{array}$ & $\begin{array}{l}\text { Keynes's } \\
\text { view }\end{array}$ \\
\hline $\begin{array}{l}\text { Fallahi and } \\
\text { Shoorkchali (2012) }\end{array}$ & 1961-2008 & Greece & $\begin{array}{l}\text { Smooth transition } \\
\text { regression analysis }\end{array}$ & U-curve \\
\hline Salih (2012) & 1970-2010 & Sudan & $\begin{array}{l}\text { Co-integration and } \\
\text { causality analysis }\end{array}$ & Wagner's law \\
\hline $\begin{array}{l}\text { Antoniou, } \\
\text { Katrakilidis \& } \\
\text { Tsaliki (2013) }\end{array}$ & 1833-1938 & Greece & $\begin{array}{l}\text { ARDL bound testing } \\
\text { analysis }\end{array}$ & Wagner's law \\
\hline $\begin{array}{l}\text { Shahbaz, Khan \& } \\
\text { Tahir (2013) }\end{array}$ & 1980-2010 & Portugal & $\begin{array}{l}\text { ARDL bound testing } \\
\text { analysis }\end{array}$ & $\begin{array}{l}\text { Keynes's } \\
\text { view }\end{array}$ \\
\hline $\begin{array}{l}\text { Dada and Adewale } \\
(2013)\end{array}$ & 1961-2011 & Nigeria & $\begin{array}{l}\text { Co-integration } \\
\text { analysis }\end{array}$ & Wagner's law \\
\hline $\begin{array}{l}\text { Asghari, Heidari \& } \\
\text { Mohseni Zonouzi } \\
(2014)\end{array}$ & 1990-2011 & $\begin{array}{l}17 \text { developing } \\
\text { countries }\end{array}$ & $\begin{array}{l}\text { Panel smooth } \\
\text { threshold regression } \\
\text { analysis }\end{array}$ & U-curve \\
\hline $\begin{array}{l}\text { Ele, Okon, Ibok and } \\
\text { Brown (2014) }\end{array}$ & 1961-2010 & Nigeria & $\begin{array}{l}\text { Co-integration and } \\
\text { causality analysis }\end{array}$ & Wagner's law \\
\hline $\begin{array}{l}\text { Ibok and Bassey } \\
\text { (2014) }\end{array}$ & 1961-2012 & Nigeria & $\begin{array}{l}\text { Co-integration and } \\
\text { causality analysis }\end{array}$ & Wagner's law \\
\hline Ono (2014) & 1960-2010 & Japan & $\begin{array}{l}\text { ARDL bound testing } \\
\text { analysis }\end{array}$ & Wagner's law \\
\hline $\begin{array}{l}\text { Chipaumire, } \\
\text { Ngirande \& Ruswa } \\
(2014)\end{array}$ & 1990-2010 & South Africa & $\begin{array}{l}\text { Co-integration } \\
\text { analysis }\end{array}$ & $\begin{array}{l}\text { Keynes's } \\
\text { view }\end{array}$ \\
\hline $\begin{array}{l}\text { Bayrakdar et al. } \\
\text { (2015) }\end{array}$ & 1998-2004 & Turkey & $\begin{array}{l}\text { Co-integration with } \\
\text { regime shift and } \\
\text { causality analysis }\end{array}$ & Wagner's law \\
\hline $\begin{array}{l}\text { Cavicchioli and } \\
\text { Pistoresi (2016) }\end{array}$ & 1962-2009 & Italy & $\begin{array}{l}\text { Co-integration } \\
\text { analysis }\end{array}$ & Wagner's law \\
\hline
\end{tabular}




\begin{tabular}{|l|l|l|l|l|}
\hline $\begin{array}{l}\text { Paparas and Stoian } \\
(2016)\end{array}$ & $1995-2015$ & Romania & $\begin{array}{l}\text { Co-integration and } \\
\text { causality analysis }\end{array}$ & Wagner's law \\
\hline $\begin{array}{l}\text { Pula and Elshani } \\
(2018)\end{array}$ & $2004-2016$ & Kosovo & $\begin{array}{l}\text { Co-integration and } \\
\text { causality analysis }\end{array}$ & $\begin{array}{l}\text { Keynes's } \\
\text { view }\end{array}$ \\
\hline $\begin{array}{l}\text { Kimaro, Keong and } \\
\text { Sea (2017) }\end{array}$ & 2002-2015 & $\begin{array}{l}\text { 25 Sub } \\
\text { Saharan } \\
\text { African } \\
\text { countries }\end{array}$ & Panel GMM analysis & $\begin{array}{l}\text { Keynes's } \\
\text { view }\end{array}$ \\
\hline $\begin{array}{l}\text { Ebaid and Bahari } \\
(2019)\end{array}$ & $1970-2015$ & Kuwait & $\begin{array}{l}\text { Co-integration and } \\
\text { causality analysis }\end{array}$ & $\begin{array}{l}\text { Keynes's } \\
\text { view }\end{array}$ \\
\hline
\end{tabular}

\section{DATA, MODEL AND METHODOLOGY}

\subsection{Data}

We employed a balanced panel dataset comprising of nine MENA countries over the period 1987-2017 based on data availability. We proxied economic growth with GDP per capita sourced from the World Bank database (2019), and government expenditure per capita as a proxy for the government expenditure sourced from the World Bank database (2019).

\subsection{Model}

We use in this paper the Pryor's (1968) version of Wagner's law (Equation 2). This study employs government consumption expenditure per capita as a proxy of government spending and the real GDP per capita as a proxy of economic growth (in natural logarithms form) as in a bivariate vector autoregressive (VAR) model as follows:

$$
\begin{aligned}
& \ln \mathrm{GEC}_{\mathrm{t}}=\beta_{0}+\beta_{1} \ln \mathrm{GDPC}_{\mathrm{t}}+\varepsilon_{\mathrm{t}} \\
& \ln \mathrm{GDPC}_{\mathrm{t}}=\alpha_{0}+\alpha_{1} \ln \mathrm{GEC}_{\mathrm{t}}+\mu_{\mathrm{t}},
\end{aligned}
$$

where ln stands for natural logarithms, GEC is the government consumption expenditure per capita; GDPC is GDP per capita; $\beta_{0}, \beta_{1}, \alpha_{0}$ and $\alpha_{1}$ are the parameters of the regression and $\varepsilon_{\mathrm{t}}$ and $\mu_{\mathrm{t}}$ are the white noise for each equation.

\subsection{Econometric Methodology}

\subsubsection{Westerlund Co-integration Panel Test}

Westerlund (2007) developed four different co-integration tests that were an extension of Banerjee et al. (1998) using the Fisher effect. These tests are based on structural dynamics; all variables should be $I(1)$ series. The four tests $\left(G_{a}, G_{t}, P_{a}\right.$ and $\left.P_{t}\right)$ are based on the error correction model (ECM); the first test $G_{a}$ and $G_{t}$ statistics test $\mathrm{H}_{0}: a_{i}=0$ for all $i$ versus $\mathrm{H}_{1}: a_{i}<0$ for at least one o the series, the other tests $\mathrm{P}_{\mathrm{a}}$ and $\mathrm{P}_{\mathrm{t}}$ statistics test $\mathrm{H}_{0}: a_{i}=0$ for all $i$ versus $\mathrm{H}_{1}: a_{i}<0$ for all cross-section units for the following ECM model (Westerlund, 2007): 


$$
\begin{aligned}
& D y_{i t}=c_{i}+a_{i 1} D y_{1 t-1}+\ldots+a_{i p} D y_{1 t-p}+b_{i 0} D x_{1 t}+b_{i 1} D x_{1 t-1}+\ldots \\
& +b_{i p} D x_{1 t-p}+a_{i}\left(y_{i t-1}-b_{1} D x_{i t-1}\right)+\mu_{i t}
\end{aligned}
$$

$\mathrm{G}_{\mathrm{t}}$ and $\mathrm{P}_{\mathrm{t}}$ tests are calculated with the standard errors of $a_{\mathrm{i}}$ by a standard way, while $G_{a}$ and $P_{a}$ are based on the Newey and West's (1994) standard errors. These four tests examine whether the co-integration relationship in a panel data is present or not by determining whether ECT (Error Correction Term) is present for all panel individuals or only for some individuals (Westerlund, 2007).

\subsubsection{Dumitrescu-Hurlin Causality Panel Test}

The general pair of panel Granger causality models is given by:

$$
\begin{aligned}
& y_{i, t}=\alpha_{0, i}+\alpha_{1, i} y_{i, t-1}+\ldots+\alpha_{l, i} y_{i, t-1}+\beta_{1, i} x_{i, t-1}+\beta_{l, i} x_{i, t-1}+\varepsilon_{i, t} \\
& x_{i, t}=\alpha_{0, j}+\alpha_{1, j} x_{j, t-1}+\ldots+\alpha_{l, j} x_{j, t-1}+\beta_{1, j} y_{j, t-1}+\beta_{l, j} y_{j, t-1}+\varepsilon_{j, t}
\end{aligned}
$$

Granger causality tests the following hypotheses (Fritsche and Pierdzioch, 2016):

$$
\begin{gathered}
\alpha_{0, i}=\alpha_{0, j}, \alpha_{1, i}=\alpha_{1, j}, \ldots, \alpha_{l, i}=\alpha_{l, j}, \forall i, j \\
\beta_{1, i}=\beta_{1, j}, \ldots, \beta_{l, i}=\beta_{l, j}, \forall i, j .
\end{gathered}
$$

However, the Dumitrescu and Hurlin (2012) tests the causality for these hypotheses:

$$
\begin{gathered}
\alpha_{0, i} \neq \alpha_{0, j}, \alpha_{1, i} \neq \alpha_{1, j}, \ldots, \alpha_{l, i} \neq \alpha_{l, j}, \forall i, j ; \\
\beta_{1, i} \neq \beta_{1, j}, \ldots, \beta_{l, i} \neq \beta_{l, j}, \forall i, j .
\end{gathered}
$$

Moreover, the pair of Homogeneous Non-Causality (HNC) null and alternative hypotheses is (Dumitrescu and Hurlin, 2012):

$$
\begin{gathered}
H_{0}: \beta_{i}=0 \forall i \operatorname{with}\left(\beta_{i}=\beta_{1, i}=\beta_{1, j}=\ldots=\beta_{l, i}=\beta_{l, j}\right) ; \\
H_{1}:\left\{\begin{array}{c}
\beta i \neq 0 \forall i=1, \ldots, N 1 \\
\beta i \neq 0 \forall i=N 1+1, N 1+2, \ldots, N
\end{array} .\right.
\end{gathered}
$$

The average statistic $W_{N, T}^{H N C}$ hypotheses can be written as follows:

$$
W_{N, T}^{H N C}=\frac{1}{N} \sum_{i=1}^{N} W_{i, t},
$$

where $W_{i, t}$ is the individual Wald statistic values for cross-section units, and the average statistic $W_{N, T}^{H N C}$, which has asymptotic distribution for $T>N$, associated with the null of HNC hypotheses, is defined as follows:

$$
Z_{N, T}^{H N C}=\sqrt{\frac{N}{2 K}}\left(W_{N, T}^{H N C}-K\right) T, N .
$$




\subsubsection{Frequency Domain Spectral Causality Test}

Fritsche and Pierdzioch (2016) used the VMA (Vector Moving Average) of the bivariate VAR model as follows:

$$
y_{t}=\psi(L) \varepsilon_{t}
$$

where $\varepsilon_{\mathrm{t}}$ is the white noise distribution; $\mathrm{L}$ is the lag operator and $\psi(\mathrm{L})$ is the lag polynomial.

The following vector shows the partitioning of $\psi(\mathrm{L})$ into parts as

$$
\psi(\mathrm{L})=\left[\begin{array}{ll}
\psi_{11}(\mathrm{~L}) & \psi_{12}(\mathrm{~L}) \\
\psi_{21}(\mathrm{~L}) & \psi_{22}(\mathrm{~L})
\end{array}\right] .
$$

In this case, Geweke (1982) suggests to test the Granger non-causality as a specific frequency $\omega$ of the following measure $M_{\mathrm{y} 1}$ cause $\mathrm{y}_{2}(\omega)$, which can be calculated as follows:

$$
\mathrm{M}_{\mathrm{y} 1 \text { cause } \mathrm{y} 2}(\omega)=\log \left[1+\frac{\left|\psi_{12}\left(\mathrm{e}^{-\mathrm{i} \omega}\right)\right|}{\left|\psi_{11}\left(\mathrm{e}^{-\mathrm{i} \omega}\right)\right|}\right],
$$

where $\mathrm{i}$ is an imaginary number.

The next step is to test if $\mathrm{y}_{1}$ causes $\mathrm{y}_{2}\left(\mathrm{M}_{\mathrm{y} 1 \text { cause }} \mathrm{y}_{2}\right)$ at any frequency $\omega$. We tested the null hypotheses $\mathrm{H}_{0}$ : $\mathrm{M}_{\mathrm{y} 1 \text { cause }} 2(\omega)=0$ (Geweke, 1982). Breitung and Candelon (2006) proposed a modified frequency domain causality using the VAR specification as follows:

$$
M_{t}=\omega_{1} M_{t-1}+\ldots+\omega_{p} M_{t-p}+\ldots+\partial_{1} N_{t-1}+\partial_{p} N_{t-p}+\varnothing_{t} .
$$

The new null hypothesis became $\mathrm{H}_{0}: R(\omega) \Omega$ where $\Omega$ constitutes a vector of coefficients of $N$ and

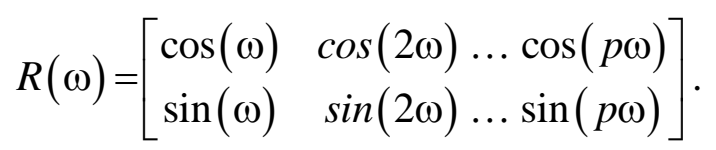

The F-statistic for this equation follows $\mathrm{F}(2, \mathrm{~T}-2 \mathrm{p})$ for $\omega \in(0, \pi)$, and it is necessary to note that high frequencies represented the short-run term causality and low frequencies represented the long-run term causality, and as considered by Toda and Phillips (1993) in co-integration systems the definition of the causality of frequency zero is equivalent to the concept of long-run causality (Toda \& Phillips, 1993). 


\section{RESULTS}

\subsection{Panel Data Analysis}

Before applying co-integration and causality panel tests, we must conduct some preliminary tests, including the CSD (Cross-Sectional Dependence) test and the unit root tests.

\subsubsection{Cross-sectional Dependence Test}

To avoid the transitions of the shocks between the countries in the sample of any panel data it is important to account for a cross-sectional dependence test. To test the CSD in our data we used 4 tests (Breusch Pagan LM test, Pesaran scaled LM test, Bias corrected scaled LM test and Pesaran CD test). The last test is the most important among the four tests proposed by Pesaran (2004), which is based on averaging the pairwise correlation coefficients on the OLS residuals (Ordinary Least squares residuals) from the individual country regressions in the full sample. Table 2 below shows the results of the four tests, and it is clear that the two variables do not suffer from cross-sectional dependence according to the rejection of the alternative hypotheses of cross-sectional dependence, which provides that the shocks in one sample do not affect another country for both variables.

Table 2. Cross-sectional Independence Test Results

\begin{tabular}{|l|l|l|l|l|}
\hline \multirow{2}{*}{ Tests } & \multicolumn{2}{c|}{ GEC } & \multicolumn{2}{c|}{ GDPC } \\
\cline { 2 - 5 } & Statistic & Prob & Statistic & Prob \\
\hline Breusch Pagan LM test & 2.105 & 0.652 & 2.859 & 0.712 \\
\hline Pesaran scaled LM test & 1.210 & 0.825 & 1.278 & 0.814 \\
\hline Bias corrected scaled LM & 2.060 & 0.670 & 1.128 & 0.825 \\
\hline Pesaran CD & 0.050 & 0.760 & 2.966 & 0.534 \\
\hline GEC: Government expenditure; GDPC: Economic Growth \\
\hline
\end{tabular}

Note: The author's calculations.

\subsubsection{Panel Unit Root Test}

As the second step of the study we applied five different panel unit root tests (Levin, Lin and Chin (LLC) test, Breitung $t$-stat (BRE) test, Im, Pesaran and Shin W-stat (IPS) test, ADF-Fisher Chi-square (ADF) test and PP-Fisher Chi-square (PP) test). The results are summarised in Table 3. The main result obtained from the Table 3 is that the two variables are I(1), so we can use the Westerlund (2007) test for the long-run relationship. 
Table 3. Unit Root Test Results

\begin{tabular}{|l|l|l|l|l|}
\hline \multirow{2}{*}{ Tests } & \multicolumn{2}{|c|}{ GEC } & \multicolumn{2}{c|}{$\Delta$ GEC } \\
\cline { 2 - 5 } & Stat & Prob & Stat & Prob \\
\hline LLC & -0.523 & 0.325 & -1.619 & $0.000^{* * *}$ \\
\hline BRE & 0.528 & 0.701 & -4.717 & $0.000^{* * *}$ \\
\hline IPS & -0.134 & 0.444 & -5.180 & $0.000^{* * *}$ \\
\hline ADF & 17.095 & 0.522 & 58.866 & $0.000^{* * *}$ \\
\hline PP & 20.669 & 0.296 & 108.012 & $0.000^{* * *}$ \\
\hline Tests & GDPC & & $\Delta$ GDPC & \\
\cline { 2 - 5 } & Stat & Prob & Stat & Prob \\
\hline LLC & -0.485 & 0.313 & -4.331 & $0.000^{* * *}$ \\
\hline BRE & 0.083 & 0.533 & -3.023 & $0.001^{* * *}$ \\
\hline IPS & -0.137 & 0.445 & -4.828 & $0.000^{* * *}$ \\
\hline ADF & 17.072 & 0.518 & 57.101 & $0.000^{* * *}$ \\
\hline PP & 24.153 & 0.150 & 129.983 & $0.000^{* * *}$ \\
\hline$\Delta:$ d & & & &
\end{tabular}

$\Delta$ : denotes the first differences; $* * *$ the significance at 1,5 and $10 \%$ significance level.

Note: the author's calculations.

\subsubsection{Co-integration Panel Test}

After confirming the absence of cross-sectional dependence and the I(1) series obtained from unit root tests, we proceeded with the co-integration tests. The Westerlund (2007) test has the null hypotheses of no co-integration by inferring whether the error correction term (ECT) in a conditional panel error correction model (ECM) is equal to zero versus the alternative hypotheses depend on the specific test. The $\mathrm{G}_{\mathrm{t}}$ and $\mathrm{G}_{\mathrm{a}}$ test examine the alternative hypotheses that at least one unit is co-integrated, and the $\mathrm{P}_{t}$ and $\mathrm{P}_{\mathrm{a}}$ tests have the alternative hypotheses that the panel is co-integrated as a whole. The results obtained from Table 4 are that there is no long-run relationship among the variables for all statistics either for normal $p$-value or for the robust $p$-value with 1000 repetitions, which means both of alternative hypothesis are rejected at $5 \%$ significance level.

Table 4. Westerlund Co-integration Test Results

\begin{tabular}{|l|l|l|l|l|}
\hline Tests & Statistic & $Z$-value & Probability & Robust $\boldsymbol{p}$-value \\
\hline $\mathrm{G}_{\mathrm{t}}$ & -2.747 & -1.405 & 0.080 & 0.060 \\
\hline $\mathrm{G}_{\mathrm{a}}$ & -10.823 & 0.524 & 0.700 & 0.190 \\
\hline $\mathrm{P}_{\mathrm{t}}$ & -5.856 & 0.550 & 0.709 & 0.610 \\
\hline $\mathrm{P}_{\mathrm{a}}$ & -8.887 & 0.022 & 0.509 & 0.360 \\
\hline$* * *:$ denotes the significance at 1,5 and $10 \%$ significance level. \\
\hline
\end{tabular}

Note: The author's calculations.

\subsubsection{Causality Panel Test}

The final step in panel data analysis in this study is the causality test using Dumitrescu and Hurlin (2012) test (DH). The optimal lag length used for the test is determined according to the AIC criterion and the results are presented in Table 5. The results reveal that economic growth homogeneously causes government expenditure at $5 \%$ significance level by a unidirectional causal relationship due to 
the absence of the causal relationship from government expenditure to economic growth. This result supports the Wagner's law hypothesis in MENA countries as a group over the period 1987-2017 using the government consumption expenditure per capita and the GDP per capita as a proxy of economic growth (Pryor 1968 equation).

Table 5. Dumitrescu Hurlin Causality Test Results

\begin{tabular}{|l|c|c|c|}
\hline \multicolumn{1}{|c|}{ Direction of causality } & $\boldsymbol{W}$-bar statistic & $\boldsymbol{Z}$-bar statistic & Prob \\
\hline GDPC does not cause GEC & 7.290 & 6.412 & 0.000 \\
\hline GEC does not cause GDPC & 3.233 & 1.320 & 0.186 \\
\hline
\end{tabular}

Note: The author's calculations.

\subsection{Time Series Analysis}

\subsubsection{Unit Root Test}

As usual, the first step in time series analysis is the unit root test, for this reason we applied the Phillips-Perron test (PP test) for the 3 equations of unit root test with constant, with constant and trend and without constant and trend. The results obtained from Table 6 show that both variables for all the countries are I(1) series. We can apply the Johansen (2002) co-integration for small samples.

Table 6. Unit Root Test Results

\begin{tabular}{|c|c|c|c|c|c|c|}
\hline \multirow[t]{2}{*}{ Countries } & \multicolumn{3}{|c|}{ GEC } & \multicolumn{3}{|c|}{$\Delta$ GEC } \\
\hline & 1 & 2 & 3 & 1 & 2 & 3 \\
\hline Algeria & -0.157 & -2.595 & 3.306 & $-4.552 * * *$ & $-4.539 * * *$ & $-4.285 * * *$ \\
\hline Egypt & -1.841 & -1.950 & 6.054 & $-3.289 * *$ & $-3.425^{*}$ & $-1.789 *$ \\
\hline Jordan & $-2.763 *$ & -2.534 & -0.938 & $-3.820 * * *$ & $-3.826 * *$ & $-3.791 * * *$ \\
\hline Mauritania & -1.384 & -1.991 & -0.088 & $-3.238 * *$ & $-3.287^{*}$ & $-3.300 * * *$ \\
\hline Morocco & -0.857 & -2.148 & 0.272 & $-5.053 * * *$ & $-6.094 * * *$ & $-5.126 * * *$ \\
\hline Sudan & 0.125 & -2.707 & 1.782 & $-5.110 * * *$ & $-5.213 * * *$ & $-4.724 * * *$ \\
\hline Tunisia & 0.006 & -2.193 & 3.655 & $-4.968 * * *$ & $-4.820 * * *$ & $-3.475 * * *$ \\
\hline Iran & -2.367 & -2.714 & -0.124 & $-5.056 * * *$ & $-4.937 * * *$ & $-5.159 * * *$ \\
\hline Turkey & 2.069 & $-3.356^{*}$ & 5.850 & $-6.223 * * *$ & $-7.349 * * *$ & $-3.472 * * *$ \\
\hline Countries & \multicolumn{3}{|c|}{ GDPC } & \multicolumn{3}{|c|}{$\triangle \mathrm{GDPC}$} \\
\hline & 1 & 2 & 3 & 1 & 2 & 3 \\
\hline Algeria & -0.027 & -2.609 & 1.231 & $-3.600 * * *$ & $-3.499 * * *$ & $-1.696^{*}$ \\
\hline Egypt & -0.562 & -1.771 & 5.518 & $-3.209 * *$ & $-3.441 * * *$ & $-1.629 *$ \\
\hline Jordan & -1.267 & -2.780 & -0.036 & $-2.777 *$ & $-3.399 * *$ & $-2.518 * *$ \\
\hline Mauritania & -0.484 & -2.306 & 1.123 & $-4.981 * * *$ & $-4.960 * * *$ & $-4.865 * * *$ \\
\hline Morocco & -1.157 & -1.881 & 2.758 & $-4.813 * * *$ & $-4.705 * * *$ & $-4.173 * * *$ \\
\hline Sudan & 1.280 & $-4.708 * * *$ & 4.567 & $-5.763 * * *$ & $-8.716^{* * *}$ & $-3.504 * * *$ \\
\hline Tunisia & -0.677 & -1.368 & 5.199 & $-4.823 * * *$ & $-4.979 * * *$ & $-2.514 * *$ \\
\hline Iran & -0.353 & -2.532 & 2.771 & $-5.251 * * *$ & $-5.188 * * *$ & $-4.408 * * *$ \\
\hline Turkey & 2.008 & -2.117 & 4.323 & $-5.707 * * *$ & $-8.163 * * *$ & $-4.267 * * *$ \\
\hline
\end{tabular}

1: denotes equation with constant; 2 : equation with constant and trend; 3 : equation without constant and trend; $* * *$ : significance at 1,5 and $10 \%$ significance level

Note: The author's calculations. 


\subsubsection{Co-integration Test}

Depending on Johansen (2002) co-integration procedure for small samples, according to both normal $p$-values and bootstrapping $p$-values with 1000 repetitions, Table 7 shows that there is no evidence of long-run relationship between the two variables in most countries (except Tunisia and Turkey) with one vector (both the $p$-value and $R p$-value are less than 0.05), which means the co-integration relationship does not exist in 7 countries.

Table 7. Co-integration Results

\begin{tabular}{|c|c|c|c|c|c|c|c|c|c|}
\hline \multirow[t]{2}{*}{ Tests } & \multicolumn{3}{|l|}{ Algeria } & \multicolumn{3}{|l|}{ Egypt } & \multicolumn{3}{|l|}{ Jordan } \\
\hline & Trace & $\begin{array}{l}p \text { - } \\
\text { value }\end{array}$ & $\begin{array}{l}R p- \\
\text { value }\end{array}$ & trace & $\begin{array}{l}p \text { - } \\
\text { value }\end{array}$ & $\begin{array}{l}R p- \\
\text { value }\end{array}$ & Trace & $\begin{array}{l}p- \\
\text { value }\end{array}$ & $R p$-value \\
\hline None & 6.844 & 0.900 & 0.992 & 18.814 & 0.077 & 0.207 & 18.255 & 0.092 & 0.566 \\
\hline At most 1 & 2.967 & 0.595 & 0.874 & 7.296 & 0.114 & 0.535 & 2.396 & 0.701 & 0.744 \\
\hline \multirow[t]{2}{*}{ Tests } & \multicolumn{3}{|c|}{ Mauritania } & \multicolumn{3}{|c|}{ Morocco } & \multicolumn{3}{|l|}{ Sudan } \\
\hline & Trace & $\begin{array}{l}p \text { - } \\
\text { value }\end{array}$ & $\begin{array}{l}R p- \\
\text { value }\end{array}$ & Trace & $\begin{array}{l}p- \\
\text { value }\end{array}$ & $\begin{array}{l}R p- \\
\text { value }\end{array}$ & Trace & $\begin{array}{l}p- \\
\text { value }\end{array}$ & $R p$-value \\
\hline None & 10.260 & 0.620 & 0.843 & 26.121 & 0.006 & 0.103 & 22.185 & 0.025 & 0.225 \\
\hline At most 1 & 1.000 & 0.936 & 0.990 & 4.127 & 0.406 & 0.655 & 8.363 & 0.071 & 0.382 \\
\hline \multirow[t]{2}{*}{ Tests } & \multicolumn{3}{|l|}{ Tunisia } & \multicolumn{3}{|l|}{ Iran } & \multicolumn{3}{|l|}{ Turkey } \\
\hline & Trace & $\begin{array}{l}p \text { - } \\
\text { value }\end{array}$ & $\begin{array}{l}R p- \\
\text { value }\end{array}$ & Trace & $\begin{array}{l}p- \\
\text { value }\end{array}$ & $\begin{array}{l}R p- \\
\text { value }\end{array}$ & Trace & $\begin{array}{l}p- \\
\text { value }\end{array}$ & $R p$-value \\
\hline None & 27.289 & 0.004 & 0.019 & 15.351 & 0.211 & 0.322 & 29.743 & 0.001 & 0.004 \\
\hline At most 1 & 6.346 & 0.171 & 0.453 & 5.924 & 0.204 & 0.360 & 7.198 & 0.119 & 0.324 \\
\hline
\end{tabular}

Note: The author's calculations.

\subsubsection{Frequency Domain Spectral Causality Test}

The final step in this paper was to examine the individual causal relationship between economic growth and government expenditure in frequency domain spectral causality depending on Breitung and Candelon (2006) procedure. The results presented in Appendix indicate that in the short-run term only two countries (Algeria and Morocco) support the Keynes's view hypothesis; this implies a unidirectional causality from government expenditure to economic growth. For the Wagner's law hypothesis (a uni-directional causality from economic growth to government expenditure) we did not find any evidence of any causal relationship in all the countries. For most countries we found no causality between economic growth and government expenditure, hence supporting the neutrality hypothesis in the short-run term. In the long-run term, evidence for the Keynes's view hypothesis was found for three countries (Algeria, Egypt and Iran) and for Wagner's law hypothesis - for two countries (Tunisia and Turkey), bidirectional causality was found for only Morocco, and the remainder (Sudan, Mauritania and Jordan) showed no causality. 
Table 8. Causality Test Results

\begin{tabular}{|l|l|l|}
\hline Countries & Short-run term & Long-run term \\
\hline Algeria & Keynes's view & Keynes's view \\
\hline Egypt & Neutrality hypotheses & Keynes's view \\
\hline Jordan & Neutrality hypotheses & Neutrality hypotheses \\
\hline Sudan & Neutrality hypotheses & Neutrality hypotheses \\
\hline Mauritania & Neutrality hypotheses & Neutrality hypotheses \\
\hline Morocco & Keynes's view & Bi-directional hypotheses \\
\hline Tunisia & Neutrality hypotheses & Wagner's law \\
\hline Iran & Neutrality hypotheses & Keynes's view \\
\hline Turkey & Neutrality hypotheses & Wagner's law \\
\hline
\end{tabular}

Note: The author's calculations.

Overall, our findings supported the neutrality hypotheses in the short-run term, suggesting that government expenditure and economic growth were independent, but in the long-run term, our findings supported Keynes's view for three countries and Wagner's law for two countries, bi-directional causality only for Morocco and the neutrality hypotheses were proved for three countries. Table 8 summarises these results.

\section{CONCLUDING REMARKS}

The main objective of this research was to examine the causal relationship between economic growth and government expenditure in 9 MENA countries based on data availability over the period of 1987-2017 using both the time series analysis and panel data analysis to get a clear idea about the causal relationship individually for each country and for the full sample. Previous studies used a time domain approach which did not allow for the distinction between time periods (short-run and long-run terms). In this study, we employed the frequency domain spectral causality test depending on Breitung and Candelon (2006) procedure, which allowed testing the causality in varying time periods in one test. We also employed the recent test for co-integration in panel data (Westerlund (2007) procedure) and the modern causality test in panel data (Dumitrescu and Hurlin (2012) test). Our results showed that there was no causal relationship between economic growth and government expenditure in the short-run term except for Algeria and Morocco (Keynes's view). We found evidence for the Keynes's view, Wagner's law and bidirectional hypotheses for three, two and one countries, respectively, but for the panel data causality we found support of Wagner's law hypothesis for the full sample. The outcomes of this study are very important for policy-makers and governments in MENA countries. We recommend that the governments in Algeria, Egypt and Iran should focus on government expenditure as an exogenous factor to impulse the economic growth in the long-run term; on the other hand, the governments in Tunisia and Turkey should focus on the economic growth as an exogenous factor to increase the size of government expenditure. 


\section{REFERENCES}

Abdullah, H., \& Maamor, S. (2010). Relationship between national product and Malaysian government development expenditure: Wagner's law validity application. International Journal of Business and Management, 5(1). http://doi.org/10.5539/ijbm.v5n1p88

Abu-Bader, S., \& Abu-Qarn, A. S. (2003). Government expenditures, military spending and economic growth: causality evidence from Egypt, Israel, and Syria. Journal of Policy Modelling, 25(6-7), 567-583. https://doi.org/10.1016/S0161-8938(03)00057-7

Agell, J., Lindh, T., \& Ohlsson, H. (1999). Growth and the public sector: A reply. European journal of political economy, 15(2), 359-366. https://doi.org/10.1016/S0176-2680(99)00011-7

Akitoby, B., Clements, B., Gupta, S., \& Inchauste, G. (2006). Public spending, voracity, and Wagner's law in developing countries. European Journal of Political Economy, 22(4), 908-924. https://doi.org/10.1016/j.ejpoleco.2005.12.001

Al-Faris, A. F. (2002). Public expenditure and economic growth in the Gulf Cooperation Council countries. Applied economics, 34(9), 1187-1193. https://doi.org/10.1080/00036840110090206

Ansari, M. I., Gordon, D. V., \& Akuamoah, C. (1997). Keynes versus Wagner: public expenditure and national income for three African countries. Applied Economics, 29(4), 543-550. https://doi.org/10.1080/000368497327038

Antoniou, A., Katrakilidis, C., \& Tsaliki,Antonis, A., Constantinos, K., \& Persefoni, T. P. (2013). Wagner's law versus Keynesian hypothesis: Evidence from pre-WWII Greece. Panoeconomicus, 60(4), 457472. http://dx.doi.org/10.2298/PAN1304457A

Armey, DR. K. (1995). The Freedom Revolution: The New Republican House Majority Leader Tells Why Big Government Failed, Why Freedom Works, And How We Will Rebuild America. Regnery Publishing.

Asghari, R., Heidari, H., \& Mohseni Zonouzi, S. J. (2014). An investigation of the impact of government size on economic growth: New Evidence from Selected Mena Countries. Iranian Journal of Economic Studies, 3(2), 63-80. https://dx.doi.org/10.22099/ijes.2014.3670

Atkinson, A. B., \& Stiglitz, J. E. (1980). Lectures on Public Economics. London, New York: McGrave-Hill.

Babatunde, M. A. (2011). A bound testing analysis of Wagner's law in Nigeria: 1970-2006. Applied Economics, 43(21), 2843-2850. https://doi.org/10.1080/00036840903425012

Banerjee, A., Dolado, J., \& Mestre, R. (1998). Error-correction mechanism tests for cointegration in a singleequation framework. Journal of time series analysis, 19(3), 267-283. https://doi.org/10.1111/1467$\underline{9892.00091}$

Bayrakdar, C. C., Çilğin, Z., Döker, M. F., \& Canpolat, E. (2015). Evidence of an active glacier in the Munzur Mountains, eastern Turkey. Turkish Journal of Earth Sciences, 24(1), 56-71. https://doi.org/10.3906/yer1403-7

Breitung, J., \& Candelon, B. (2006). Testing for short-and long-run causality: A frequency-domain approach. Journal of Econometrics, 132(2), 363-378. https://doi.org/10.1016/j.jeconom.2005.02.004

Burney, N. A. (2002). Wagner's hypothesis: evidence from Kuwait using cointegration tests. Applied Economics, 34(1), 49-57. https://doi.org/10.1080/00036840010027540

Cavicchioli, M., \& Pistoresi, B. (2016). Testing threshold cointegration in Wagner's Law: The role of military spending. Economic Modelling, 59, 23-31. https://doi.org/10.1016/j.econmod.2016.06.011

Chipaumire, G., Ngirande, H., \& Ruswa, Y. (2014). The Impact of Government Spending on Economic Growth: Case South Africa. Mediterranean Journal of Social Sciences, 5(1), 109. 10.5901/mjss.2014.v5n1p109

Dada, M. A., \& Adewale, O. A. (2013). Is Wagner's law a myth or a reality? Empirical evidence from Nigeria. International Journal of Development and Economic Sustainability, 1(1), 123-137.

Dar, A. A., \& AmirKhalkhali, S. (2002). Government size, factor accumulation, and economic growth: evidence from OECD countries. Journal of Policy Modelling, 24(7-8), 679-692. https://doi.org/10.1016/S0161-8938(02)00163-1

Dolado, J. J., \& Lütkepohl, H. (1996). Making Wald tests work for cointegrated VAR systems. Econometric Reviews, 15(4), 369-386. https://doi.org/10.1080/07474939608800362

Dritsakis, N., \& Adamopoulos, A. (2004). A causal relationship between government spending and economic development: an empirical examination of the Greek economy. Applied Economics, 36(5), 457-464. https://doi.org/10.1080/00036840410001682151

Dumitrescu, E. I., \& Hurlin, C. (2012). Testing for Granger non-causality in heterogeneous panels. Economic Mmodelling, 29(4), 1450-1460. https://doi.org/10.1016/j.econmod.2012.02.014

E.Stiglitz, A. B. (1980). Lecture on Public Economics. McGrave-Hill

Ebaid, A., \& Bahari, Z. (2019). The Nexus between Government Expenditure and Economic Growth: Evidence of the Wagner's Law in Kuwait. Review of Middle East Economics and Finance, 15(1), 1-9. https://doi.org/10.1515/rmeef-2017-0001 
Ele, I. E., Okon, I. E., Ibok, O. W., \& Brown, I. N. (2014). Analysis of Agricultural public capital expenditure and agricultural economic growth in Nigeria (1961-2010). American Journal of Experimental Agriculture, 4(4), 443-456. https://doi.org/10.9734/AJEA/2014/6472

Fallahi, F., \& Montazeri Shoorkchali, J. (2012). Government size and economic growth in Greece: A smooth transition approach. MPRA Paper No. 74078.

Fritsche, U., \& Pierdzioch, C. (2016). Animal spirits, the stock market, and the unemployment rate: Some evidence for German data (No. 1/2016). DEP (Socioeconomics) Discussion Papers, Macroeconomics and Finance Series.

Geweke, J. (1982). Measurement of linear dependence and feedback between multiple time series. Journal of the American statistical association, 77(378), 304-313.

Goffman, J. J. (1968). On the Empirical Testing of Wagner's Law: A Technical Note. Public Finance, 3(3), $359-364$.

Halicioĝlu, F. (2003). Testing Wagner's law for Turkey, 1960--2000. Review of Middle East Economics and Finance, 1(2), 129-140.

Hansson, P., \& Henrekson, M. (1994). A new framework for testing the effect of government spending on growth and productivity. Public choice, 81(3-4), 381-401. https://doi.org/10.1007/BF01053239

Ibok, O. W., \& Bassey, N. E. (2014). Wagner's Law Revisited: The Case Ofof Nigerian Agricultural Sector (1961-2012). International Journal of Food and Agricultural Economics (IJFAEC), 2(3)1128-201692045), 19-32. 10.22004/ag.econ.186264https://doi.org/10.22004/ag.econ.186264

Islam, A. M. (2001). Wagner's law revisited: cointegration and exogeneity tests for the USA. Applied Economics Letters, 8(8), 509-515. https://doi.org/10.1080/13504850010018743

Jiranyakul, K., \& Brahmasrene, T. (201307). The Relationship between Government Expenditures and Economic Growth in Thailand. SSRN, Working Paper. http://dx.doi.org/10.2139/ssrn.2260035

Johansen, S. (2002). A small sample correction for the test of cointegrating rank in the vector autoregressive model. Econometrica, 70(5), 1929-1961. https://doi.org/10.1111/1468-0262.00358

Kalam, M. A., \& Aziz, N. (2009). Growth of government expenditure in Bangladesh: An Empirical enquiry into the validity of Wagner's law. Global Economy Journal, 9(2), 1850162. https://doi.org/10.2202/15245861.1451

Karhan, G. (2018). The Relationship Between Public Expenditures and Economic Growth: A Panel VAR approach. Cumhuriyet Üniversitesi İktisadi ve İdari Bilimler Dergisi, 19(2), 35-43.

Keynes, J. M. (1936). The General Theory of Employment, Interest, and Money. London: Macmillan.

Kimaro, E. L., Keong, C. C., \& Sea, L. L. (2017). Government Expenditure, Efficiency and Economic Growth: A Panel Analysis of Sub Saharan African Low-Income Countries. African Journal of Economic Review, 5(2), 34-54. https://doi.org/10.22004/ag.econ.264565

King, J. E. (Ed.). (2012). The Elgar companion to post Keynesian economics. Edward Elgar Publishing.

Liu, L. C. H., Hsu, C. E., \& Younis, M. Z. (2008). The association between government expenditure and economic growth: Granger causality test of US data, 1947-2002. Journal of Public Budgeting, Accounting \& Financial Management, 20(4), 439-452. https://doi.org/10.1108/JPBAFM-20-04-2008-B002

Loizides, J., \& Vamvoukas, G. (2005). Government Expenditure and Economic Growth: Evidence from Trivariate Causality Testing. Journal of Applied Economics, 8(1), 125-152. https://doi.org/10.1080/15140326.2005.12040621

Magazzino, C. (2012). Wagner's Law and Augmented Wagner's Law in EU-27. A Time-Series Analysis on Stationarity, Cointegration and Causality, International Research Journal of Finance and Economics, 89, 205-220.

Mann, A. J. (1980). Wagner's law: An econometric test for Mexico, 1925-1976. National Tax Journal (pre1986), 33(2), 189.

Menyah, K., \& Wolde-Rufael, Y. (2012). Wagner's Law Revisited: A Note from South Africa. South African Journal of Economics, 80(2), 200-208. https://doi.org/10.1111/j.1813-6982.2011.01275.x

Michas, N. A. (1975). Wagner's Law of Public Expenditures: What Is the Appropriate Measurement for a Valid Test? Public Finance $=$ Finances Publiques, 30(1), 77-85.

Musgrave, R. A. (1969). Cost-benefit analysis and the theory of public finance. Journal of Economic Literature, 7(3), 797-806.

Narayan, P. K., Prasad, A., \& Singh, B. (2008). A test of the Wagner's hypothesis for the Fiji Islands. Applied Economics, 40(21), 2793-2801. https://doi.org/10.1080/00036840600972472

Newey, W. K., \& West, K. D. (1994). Automatic lag selection in covariance matrix estimation. The Review of Economic Studies, 61(4), 631-653. https://doi.org/10.2307/2297912

Ono, H. (2014). The government expenditure-economic growth relation in Japan: an analysis by using the ADL test for threshold cointegration, Applied Economics, 46(28), 3523-3531. https://doi.org/10.1080/00036846.2014.932046

Paparas, D., \& Stoian, A. (2016). The validity of Wagner's Law in Romania during 1995-2015. MPRA Paper.

Peacock, A. T., \& Wiseman, J. (1961). Front matter, the growth of public expenditure in the United Kingdom. In The growth of public expenditure in the United Kingdom. (pp. 32-0). Princeton University Press. 
Pesaran, M. H. (2004). General diagnostic tests for cross section dependence in panels. CESifo Working paper, No. 1229.

Pryor, F. L. (1968). Public expenditures in communist and capitalist nations. RD Irwin.

Pula, L., \& Elshani, A. (2018). The Relationship Between Public Expenditure and Economic Growth in Kosovo: Findings from a Johansen Co-Integrated Test and a Granger Causality Test. Ekonomika (Economics), 97(1), 47-62. https://doi.org/10.15388/ekon.2018.1.11778

Ram, R. (1986). Government size and economic growth: A new framework and some evidence from crosssection and time-series data. The American Economic Review, 76(1), 191-203.

Riedl, B. M. (2010). Why Government Spending Does Not Stimulate Economic Growth: Answering the Critics. Wall Street Journal, updated Jan., 8.

Salih, M. A. R. (2012). The relationship between economic growth and Government expenditure: Evidence from Sudan. International Business Research, 5(8), 40-46. https://doi.org/10.5539/ibr.v5n8p40

Shahbaz, M., Khan, S., \& Tahir, M. I. (2013). The dynamic links between energy consumption, economic growth, financial development and trade in China: fresh evidence from multivariate framework analysis. Energy economics, 40, 8-21. https://doi.org/10.1016/j.eneco.2013.06.006

Sheehey, E. J. (1993). The effect of government size on economic growth. Eastern Economic Journal, 19(3), $321-328$.

Slemrod, J., Gale, W. G., \& Easterly, W. (1995). What do cross-country studies teach about government involvement, prosperity, and economic growth? Brookings papers on economic activity, 1995(2), 373431. https://doi.org/10.2307/2534615

Tanzi, V., \& Zee, H. H. (1997). Fiscal policy and long-run growth. Staff Papers, 44(2), 179-209. https://doi.org/10.2307/3867542

Toda, H. Y., \& Phillips, P. C. (1993). Vector autoregressions and causality. Econometrica: Journal of the Econometric Society, 61(6), 1367-1393. https://doi.org/10.2307/2951647

Toda, H. Y., \& Yamamoto, T. (1995). Statistical inference in vector autoregressions with possibly integrated processes. Journal of Econometrics, 66(1-2), 225-250. https://doi.org/10.1016/0304-4076(94)01616-8

Wagner, A. (1892). Grundlegung der politischen Ökonomie (Vol. 1). CF Winter.

Westerlund, J. (2007). Testing for Error Correction in Panel Data. Oxford Bulletin of Economics and statistics, 69(6), 709-748. https://doi.org/10.1111/j.1468-0084.2007.00477.x

World Bank (2019). World Development Indicators. World Bank database. Retrieved May 2020 from https://databank.worldbank.org/source/world-development-indicators

\section{AUTHOR'S SHORT BIOGRAPHY}

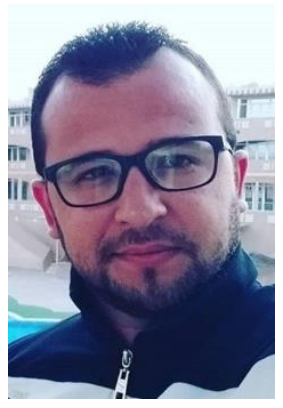

Hicham Ayad received the Master degree in economics from Tlemcen University in Algeria in 2013 and the PhD degree in 2017 in quantitative economics. The author has been a Lecturer at the University Centre in Maghnia-Tlemcen-Algeria since 2018.

The main research interest is the econometric studies in macroeconomics (poverty, financial development, trade).

E-mail: a_hichem210@hotmail.fr

ORCID iD: https://orcid.org/0000-0003-1624-3456 


\section{APPENDIX}
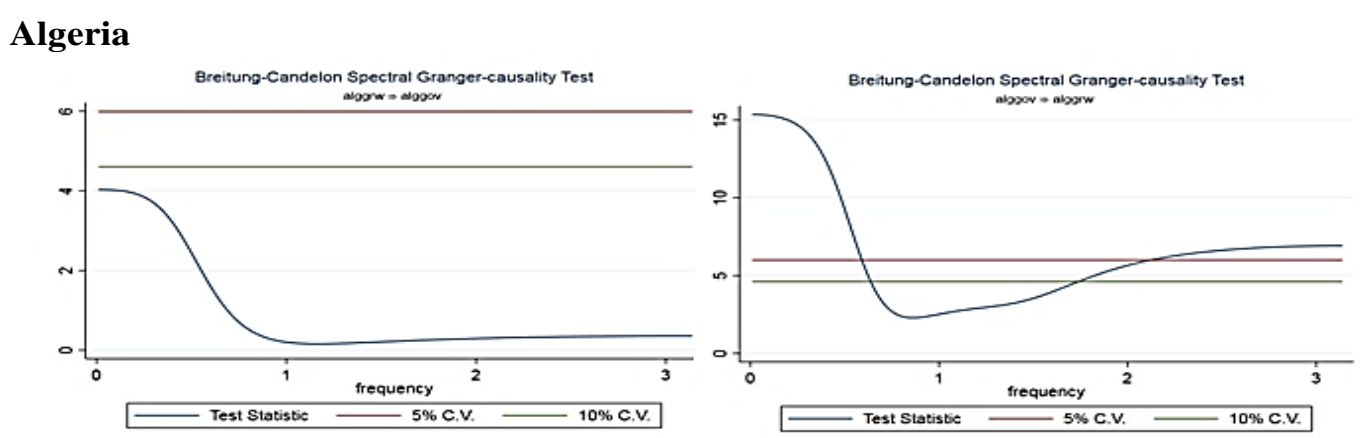

Source: Author's calculations using Stata

\section{Egypt}

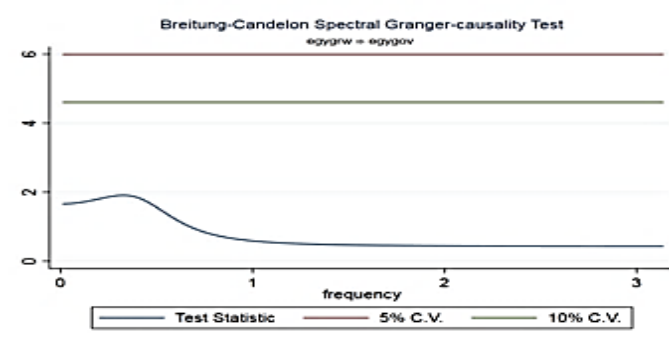

Source: Author's calculations using Stata

\section{Jordan}

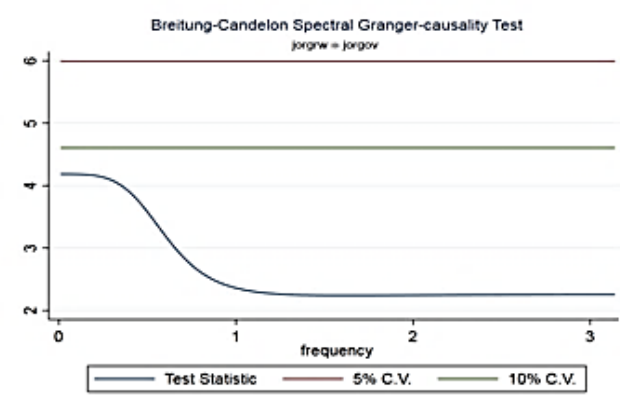

Source: Author's calculations using Stata

\section{Mauritania}

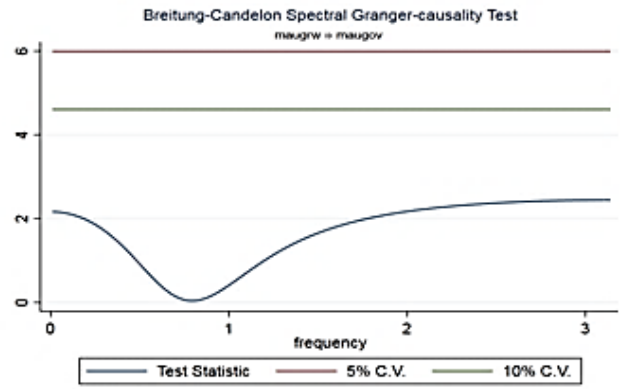

Source: Author's calculations using Stata
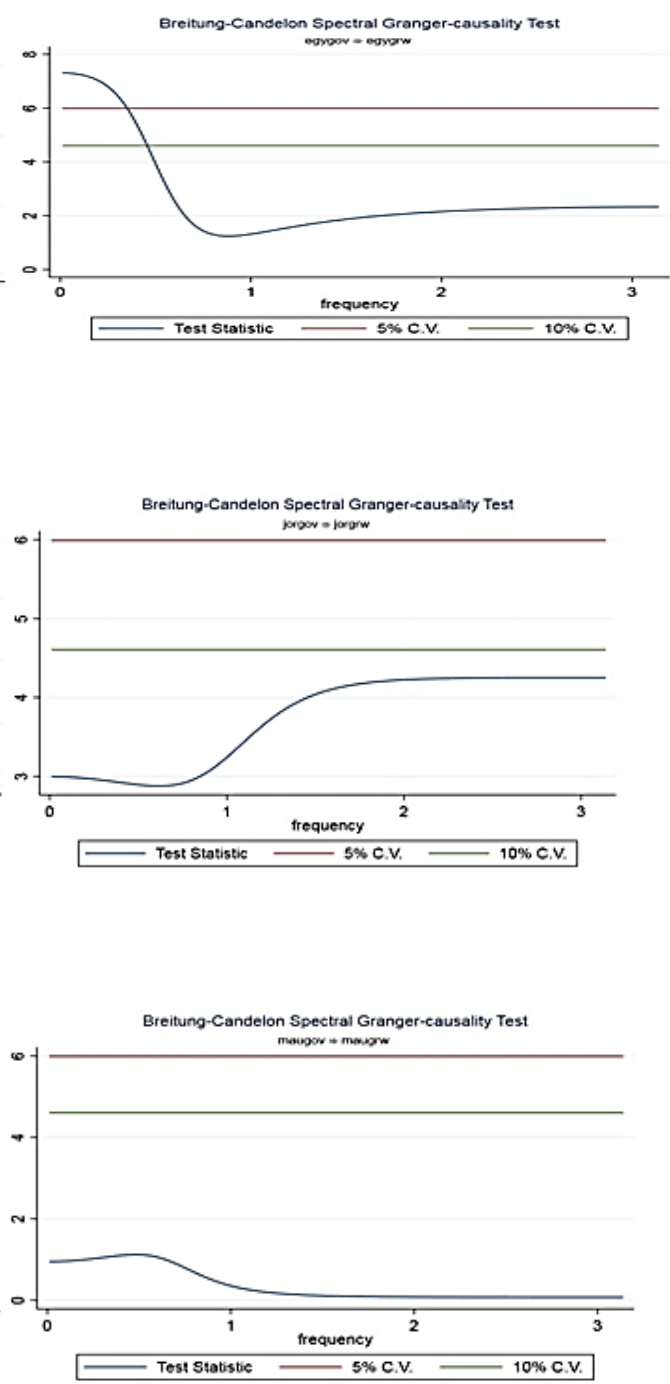


\section{Morocco}
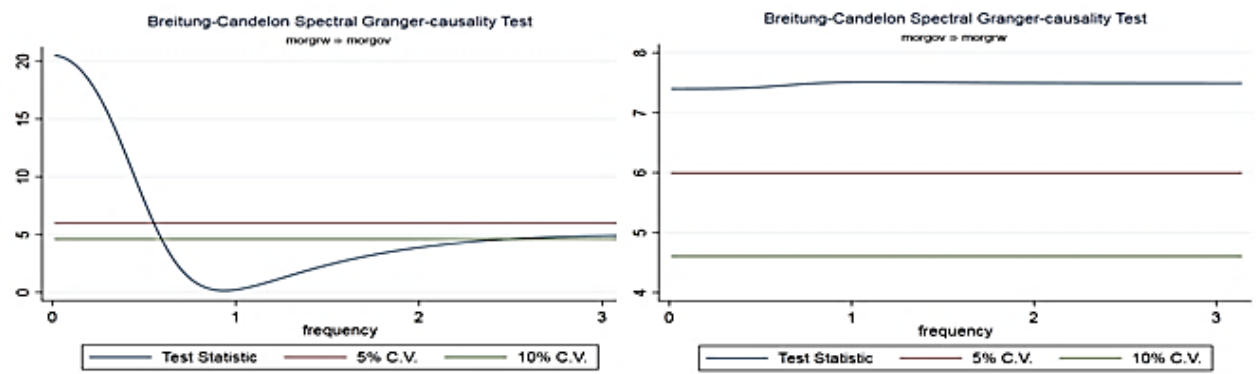

Source: Author's calculations using Stata

\section{Sudan}
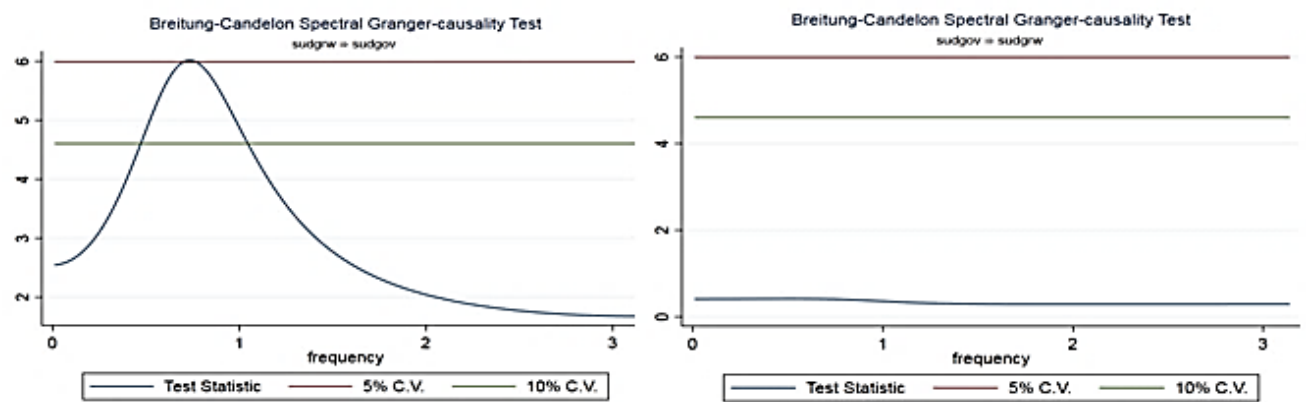

Source: Author's calculations using Stata

\section{Tunisia}
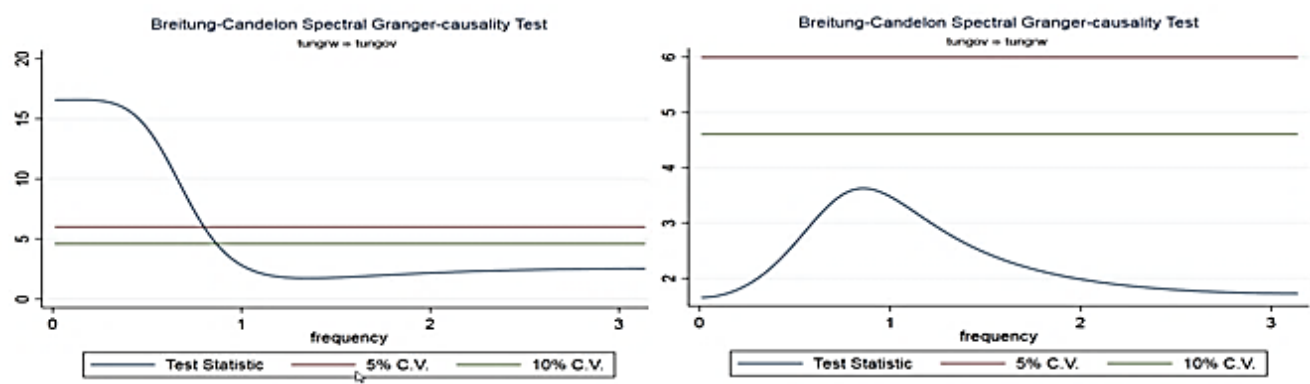

Source: Author's calculations using Stata

\section{Iran}
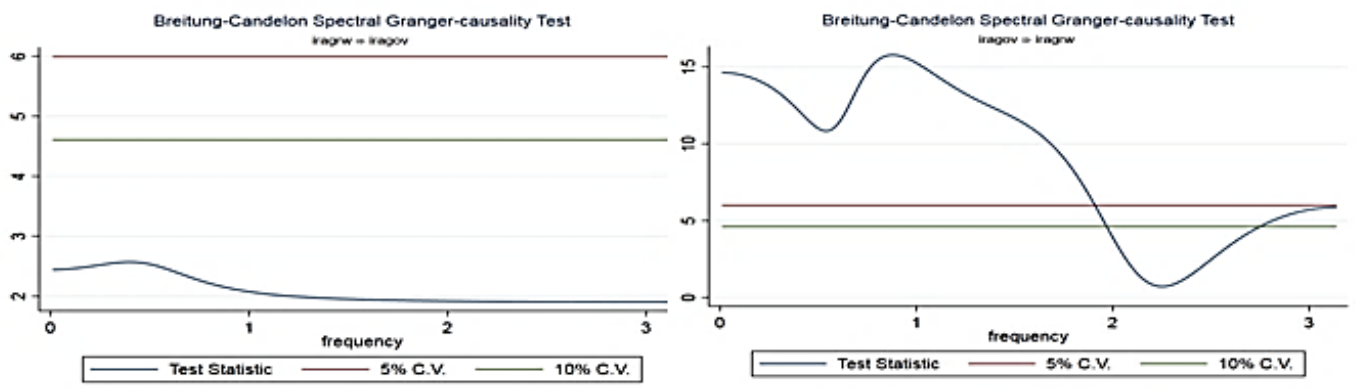

Source: Author's calculations using Stata 


\section{Turkey}
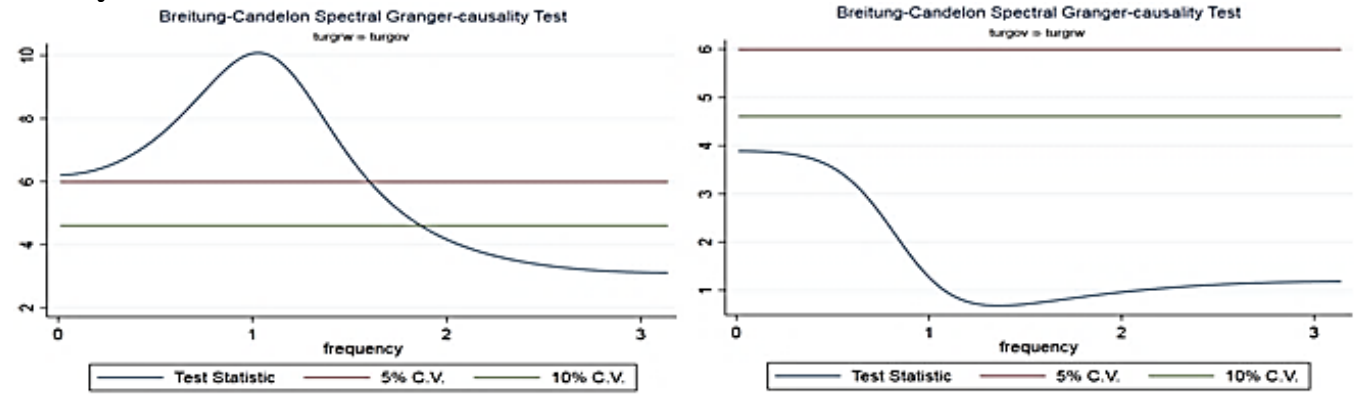

Source: Author's calculations using Stata 